\title{
DESCRIPTION OF A NEW SPECIES OF FISH, BLEEKERIA GILLI.
}

\author{
By Tarleton H. Bean, M. D., \\ Curator of the Department of Fishes.
}

This species of sand-lance is described from eleven examples belonging to the U. S. National Museum. The locality is doubtful, the data being lost, but it is probable that they belong to Dr. Stimpson's collections from the Pacific. The largest example is five inches long, the smallest three inches.

BLEEKERIA GILLI, new species.

Diagnosis.-D. 47 ; A. 22 to 24 ; P. 15 . Scales 97 , of which 90 are in the lateral line; transverse rows 3 to 14 . The scales are regularly imbricated and the skin is entirely without longitudinal folds. The lateral line is wanting on the last six or seven scales; it ascends abruptly over the pectoral and follows not far from the dorsal outline, terminating between the end of the dorsal and the origin of the caudal.

Gill-rakers numerous, smooth along posterior margin, long and slender, the longest about as long as the eye. Branchiostegals 7. Pseudobranchiæ large, about 20 laminæ. The pectoral reaches to the thirteenth row of scales, its length equal to length of eye and snout combined. The maxilla extends to below the front of the eye; intermaxilla very protractile, forming about two-thirds of the length of upper jaw. Labial fold of mandible well developed. Head naked. Dorsal and anal received in a deep sheath. A small, thin, ovate flap between the anal and the genital opening, this flap covering the latter opening.

Eye large, one-fifth of head, greater than interorbital space. Tip of preoperculum produced into a short, triangular flap. Subopereulum with three well-defined radiating striæ. Angle of preoperculum with several raised tubular ridges. Many of the scales, especially posteriorly, with coarse denticulations around the exposed margin. Head one-fourth of total length without eaudal; greatest depth one-half head, nearly one-eighth of the standard body length. The distance of the dorsal origin from the tip of snout nearly equals the length of the 
head. Vent a little nearer root of caudal than to origin of pectoral. Caudal forked; the middle rays nearly two-thirds as long as the outer. Back grayish brown; sides and lower parts silvery. General appearance of Ammodytes.

Type.-No. 45384, U.S.N.M.

The species is dedicated to Dr. Theodore Gill, thereby associating the names of two eminent ichthyologists, whose contributions to this branch of zoology have in many respects followed along similar lines. 


\section{$2 \mathrm{BHL}$ Biodiversity Heritage Library}

Bean, Tarleton H. 1895. "Description of a new species of fish, Bleekeria gilli." Proceedings of the United States National Museum 17(1028), 629-630. https://doi.org/10.5479/si.00963801.17-1028.629.

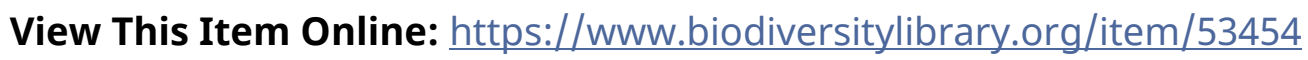

DOI: https://doi.org/10.5479/si.00963801.17-1028.629

Permalink: https://www.biodiversitylibrary.org/partpdf/52163

\section{Holding Institution}

Smithsonian Libraries

\section{Sponsored by}

Smithsonian

\section{Copyright \& Reuse}

Copyright Status: Public domain. The BHL considers that this work is no longer under copyright protection.

This document was created from content at the Biodiversity Heritage Library, the world's largest open access digital library for biodiversity literature and archives. Visit BHL at https://www.biodiversitylibrary.org. 